\title{
Effect of 2-hydroxy-4-methylthio-butanoic acid on ruminal fermentation, bacterial distribution, digestibility, and performance of lactating dairy cows
}

\author{
C. Lee, ${ }^{*}$ J. Oh, ${ }^{*}$ A. N. Hristov, ${ }^{* 1}$ K. Harvatine, ${ }^{*}$ M. Vazquez-Anon, $\dagger$ and G. I. Zanton $\dagger$ \\ *Department of Animal Science, Pennsylvania State University, University Park 16802 \\ †Novus International Inc., St. Charles, MO 63304
}

\begin{abstract}
The objective of this experiment was to test the effect of a Met analog, 2-hydroxy-4-methylthio-butanoic acid (HMTBa), on ruminal fermentation and microbial protein synthesis, nutrient digestibility, urinary $\mathrm{N}$ losses, and performance of dairy cows. Eight multiparous lactating Holstein dairy cows were assigned to 4 levels of HMTBa [0 (control), 0.05, 0.10, and $0.15 \%$ (dry matter basis)] in a replicated $4 \times 4$ Latin square trial. Experimental periods were $28 \mathrm{~d}$, including $21 \mathrm{~d}$ for adaptation. Ruminal ammonia and microbial $\mathrm{N}$ were labeled through a 6-d intraruminal infusion of ${ }^{15} \mathrm{NH}_{4} \mathrm{Cl}$, and microbial protein synthesis in the rumen was estimated using the reticular sampling technique. Treatment had no effect on dry matter intake (28.4 to $29.8 \mathrm{~kg} / \mathrm{d}$ ), milk yield (44.1 to $45.3 \mathrm{~kg} / \mathrm{d}$ ), feed efficiency, and milk composition. Total-tract apparent digestibility of nutrients was generally not affected by treatment, except digestibility of crude protein and starch decreased quadratically with HMTBa supplementation. Fecal, but not urinary, and total excreta $\mathrm{N}$ losses were increased quadratically by HMTBa. Ruminal pH, ammonia concentration, protozoal counts, and the major volatile fatty acids were not affected by treatment. Microbial $\mathrm{N}$ outflow from the rumen was linearly increased by HMTBa. 2-Hydroxy-4-methylthio-butanoic acid linearly increased the proportion of Fecalibacterium and quadratically decreased the proportion of Eubacterium in ruminal contents. Of the individual bacterial species, HMTBa increased or tended to increase Prevotella loescheii and Prevotella oralis. 2-Hydroxy-4-methylthiobutanoic acid linearly increased the concentration (and yield) of 15:0 in milk fat. In the conditions of this crossover experiment, HMTBa had no effect on feed intake and performance of dairy cows, decreased dietary crude protein digestibility, and increased microbial $\mathrm{N}$ outflow from the rumen.
\end{abstract}

Received September 27, 2014.

Accepted October 26, 2014.

${ }^{1}$ Corresponding author: anh13@psu.edu
Key words: 2-hydroxy-4-methylthio-butanoic acid, rumen fermentation, rumen bacteria, dairy cow

\section{INTRODUCTION}

Since early work in the 1960s and 1970s, Met has been considered a limiting or first limiting AA for lactating dairy cows in the United States (Griel et al., 1968; Broderick et al., 1970, 1974; Schwab et al., 1976). Various forms of the Met analog, 2-hydroxy-4-(methylthio)butanoic acid (HMTBa), are commercially available and have been used primarily as sources of Met with variable rumen fermentation and production responses in dairy cows (Noftsger et al., 2005; Chen et al., 2011). Reportedly, HMTBa is rapidly absorbed and efficiently converted to L-Met in the tissue of nonruminant species (Knight and Dibner, 1984; Dibner, 2003; Jendza et al., 2011) and ruminants (McCollum et al., 2000; Lobley et al., 2006) and serves as a source of methyl groups or Cys synthesis. The bioavailability of HMTBa relative to that of DL-Met has been extensively studied with reports in the literature of 60 to $80 \%$ (depending on the function: BW gain, feed conversion, breast meat yield) in broiler chicken (Zelenka et al., 2013) and several meta-analyses have reported bioavailability of 81 to $100 \%$ in poultry (Vazquez-Añon et al., 2006; Vedenov and Pesti, 2010). A recent study with ${ }^{13} \mathrm{C}$-labeled HMTBa infused intravenously demonstrated that the compound can serve as a source of Met and also has a Met-sparing effect in dairy cows, with $15 \%$ of the milk protein Met originating from direct conversion of HMTBa to Met (Lapierre et al., 2011).

Limited data have suggested a possible effect of HMTBa on rumen fermentation, fiber degradability, and microbial protein synthesis. With a reported ruminal degradability of 50\% or more (Koenig et al., 1999, 2002; Noftsger et al., 2005), HMTBa could affect microbial fermentation by a direct stimulatory effect of Met on certain cellulolytic bacteria or through an indirect effect on the noncellulolytic species in the rumen (Martin et al., 2013). Vazquez-Añon et al. (2001) reported, for example, a quadratic increase in bacterial $\mathrm{N}$ outflow and the efficiency of bacterial $\mathrm{N}$ synthesis in continuous 
culture fermenters. In vivo data on the effect of HMTBa on ruminal fermentation and specifically microbial protein synthesis are scarce or lacking. Although in vitro systems are often used to study rumen fermentation, in vitro data do not always correspond to in vivo responses and need verification in live animal experiments (Hristov et al., 2012).

Thus, the main objective of this study was to investigate the effect of HMTBa on ruminal fermentation, bacterial genus and species composition, and microbial protein synthesis in dairy cows. Our hypothesis was that HMTBa may stimulate microbial protein synthesis and specific cellulolytic bacteria in the rumen. Production effects, total-tract apparent digestibility of nutrients, urinary $\mathrm{N}$ losses, and milk FA composition effects of HMTBa were also studied.

\section{MATERIALS AND METHODS}

Animals involved in these experiments were cared for according to the guidelines of the Pennsylvania State University Animal Care and Use Committee. The committee reviewed and approved the experiment and all procedures carried out in the study.

\section{Animals and Experimental Design}

This experiment used 8 lactating multiparous Holstein cows in a $4 \times 4$ Latin square design, balanced for residual effects, with 2 concurrent squares. Cows were $51(\mathrm{SD}=3.9) \mathrm{DIM}$ at the beginning of the experiment and had an average BW during the trial of 660 (SD $=67.3) \mathrm{kg}$. Cows were fitted with soft plastic ruminal cannulas (10.2 cm internal diameter; Bar Diamond Inc., Parma, ID). The trial had 4 experimental periods, each $28 \mathrm{~d}$ in duration. Within period, the first $21 \mathrm{~d}$ served as adaptation and the remaining $7 \mathrm{~d}$ were used for sample and production data collection. Animals were managed according to the current standard practices at the dairy facility; recombinant bST was administered at the beginning (i.e., d 1) and in the middle (d 14) of each experimental period. The following 4 treatments were tested in this trial: control, $0 \%$ HMTBa (dietary DM basis); low, 0.05\% HMTBa (as 0.057\% Alimet, Novus International Inc., St. Charles, MO); medium, $0.10 \%$ HMTBa $(0.114 \%$ Alimet); and high, 0.15\% HMTBa $(0.171 \%$ Alimet). The basal diet was formulated to meet or exceed the $\mathrm{NE}_{\mathrm{L}}$ and $\mathrm{MP}$ requirements of a Holstein cow with $660 \mathrm{~kg}$ of BW producing $45 \mathrm{~kg}$ of milk/d with $3.60 \%$ milk fat and $3.05 \%$ true milk protein (NRC, 2001). Diets were fed as TMR once daily at 0800 $\mathrm{h}$ targeting 5 to $10 \%$ refusals. The HMTBa was fed through a premix that contained $100 \%$ fine ground corn (control) or $3.33 \%$ HMTBa, $6.67 \%$ HMTBa, or $10 \%$
HMTBa replacing fine ground corn for low, medium, or high HMTBa, respectively. The premix was top-dressed once daily mixed with a small portion of the TMR, replacing an equivalent amount of corn grain. Cows consume most feed after new feed delivery and after milking (DeVries et al., 2003), and although we did not measure HMTBa consumption, it is safe to assume that the HMTBa premix was completely consumed. Cows had continuous access to a fresh water source.

\section{Sampling, Markers, and Measurements}

During the entire experiment, TMR offered and refusals were recorded daily. Samples of the forages were collected once weekly and samples of the TMR and refusals were collected twice weekly. Samples of the concentrate feeds were collected once per experimental period. Samples were dried for $48 \mathrm{~h}$ at $65^{\circ} \mathrm{C}$ in a forcedair oven and ground in a Wiley Mill (A. H. Thomas Co., Philadelphia, PA) through a 1-mm sieve for analysis. Composite (equal DM weight basis) samples of the TMR were submitted to Cumberland Valley Analytical Services (Maugansville, MD) for wet chemistry analyses of $\mathrm{CP}, \mathrm{NDF}, \mathrm{ADF}$, ether extract, Ca, P, and estimated $\mathrm{NE}_{\mathrm{L}}$ (details at http://www.foragelab.com/Resources/ Lab-Procedures, accessed June 26, 2014). Organic matter was determined following the procedure of AOAC International (2000). Composite TMR samples were also analyzed for starch and indigestible NDF (iNDF). Indigestible NDF (used as an intrinsic digestibility and large particulate matter marker) was analyzed according to Huhtanen et al. (1994), except 25- $\mu \mathrm{m}$ pore size filter bags (Ankom Technology, Macedon, NY) were used for the ruminal incubation. Starch was analyzed using an enzymatic-colorimetric procedure (Knudsen, 1997). Feed refusals were only analyzed for DM, and intake of nutrients was not corrected for composition of the refusals.

The reticular sampling (Hristov, 2007) and triplemarker (France and Siddons, 1986) techniques were used to estimate microbial protein outflow from the rumen. Markers, sampling, sample processing, and calculations were as described in Hristov (2007). Briefly, iNDF, Yb-acetate $4 \mathrm{H}_{2} \mathrm{O}$ (Chemos $\mathrm{GmbH}$, Regenstauf, Germany), and Cr-EDTA (Binnerts et al., 1968) were used as markers for the large and small particles and fluid phases of ruminal contents, respectively. Microbial protein was labeled with ${ }^{15} \mathrm{NH}_{4} \mathrm{Cl}$ (Cambridge Isotope Laboratories Inc., Andover, MA). All markers, except iNDF, were continuously infused into the rumen, through the rumen cannula, using peristaltic pumps. Markers were diluted in distilled water and infused for a total of $6 \mathrm{~d}$ (d 22 through 27 of each experimental period). Marker solution infusion rate was 1,759 (SD 
$=81)$ for $\mathrm{Cr}$ and $\mathrm{Yb}$ and $1,750(\mathrm{SD}=80) \mathrm{mL} / \mathrm{cow}$ per $\mathrm{d}$ for ${ }^{15} \mathrm{~N}$. Chromium and $\mathrm{Yb}$ markers were infused through one line and ${ }^{15} \mathrm{~N}$ through another. Average infusion rates were 2.7 for $\mathrm{Cr}, 2.1$ for $\mathrm{Yb}$, and $250 \mathrm{mg} /$ cow per day for ${ }^{15} \mathrm{~N}$. Actual $\mathrm{Cr}$ and $\mathrm{Yb}$ doses were estimated based on $\mathrm{Cr}$ and $\mathrm{Yb}$ output in fecal DM. Samples of reticular contents were collected during the last $2 \mathrm{~d}$ of the infusion; at 0800,1400 , and $2000 \mathrm{~h}(\mathrm{~d} 26)$; and at 0200, 0500, 1100, 1700, and $2200 \mathrm{~h}(\mathrm{~d} \mathrm{27})$ and processed as in Hristov (2007). One reticular contents sample was collected before initiation of the marker infusion and analyzed for background concentrations of $\mathrm{Cr}, \mathrm{Yb}$, and ${ }^{15} \mathrm{~N}$. Chromium and $\mathrm{Yb}$ were analyzed at the University of Missouri-Columbia's Agricultural Experiment Station Chemical Laboratory (method 968.08D[b], AOAC International, 2002 and Combs and Satter, 1992, respectively) and ${ }^{15} \mathrm{~N}$ enrichment was analyzed on a Delta V Advantage Isotope-Ratio Mass Spectrometer (Thermo Finnigan MAT GmbH, Bremen, Germany) interfaced with a Costech ECS 4010 C/N/S elemental analyzer (Costech Analytical Technologies Inc., Valencia, CA). Samples were pulverized using a Mixer Mill MM 200 (Retsch GmbH, Haan, Germany) before the ${ }^{15} \mathrm{~N}$ analysis. Bacterial pellets were isolated from composite samples (volume based, per cow and experimental period) of reticular contents by differential centrifugation (Hristov and Ropp, 2003) and analyzed for total purines (Hristov et al., 2005a) and ${ }^{15} \mathrm{~N}$ enrichment. The proportion of microbial $\mathrm{N}$ in the NAN of reticular contents was estimated based on $\delta^{15} \mathrm{~N}$ of the bacterial standard isolated from reticular samples as follows: background-corrected $\delta^{15} \mathrm{~N}(\%)$ of NAN in reticular contents (large particles, small particles, or fluid) $\div$ background-corrected $\delta^{15} \mathrm{~N}(\%)$ of reticular bacterial standard. Microbial $\mathrm{N}$ outflow from the rumen was calculated based on the concentration of microbial $\mathrm{N}$ in NAN of the reticular large and small particulate matter and fluid phase and the outflow rates of these phases calculated using the triple marker technique of France and Siddons (1986) as described in Hristov (2007).

Milk samples were collected before (background) and on the last $2 \mathrm{~d}$ of the marker infusion (d 26 and 27 of each experimental period) and processed to isolate milk protein (Hristov and Ropp, 2003), which was freeze-dried and analyzed for $\delta^{15} \mathrm{~N}$. The contribution of rumen microbial $\mathrm{N}$ to milk protein $\mathrm{N}$ was estimated as background-corrected $\delta^{15} \mathrm{~N}(\%)$ of milk protein : background-corrected $\delta^{15} \mathrm{~N}(\%)$ of reticular bacterial standard. The basis for this approach is explained in Hristov et al. (2005a).

Spot fecal (about $500 \mathrm{~g}$ ) and urine (about $300 \mathrm{~mL}$ per sampling) samples were collected during each experimental period at the same time points as the reticular samples. Fecal samples were dried at $65^{\circ} \mathrm{C}$ in a forcedair oven for $48 \mathrm{~h}$ and then composited (equal dry weight basis) by cow and period. Composite samples were analyzed for OM, CP, NDF, ADF, and starch. Neutraldetergent fiber and ADF were analyzed using Ankom's A200 fiber analyzer (Ankom Technology, Macedon, NY) based on Van Soest et al. (1991), using amylase and sodium sulfide in the NDF analysis. An aliquot of each composite fecal sample was analyzed for $\mathrm{N}$ on a Costech ECS 4010 C/N/S elemental analyzer (Costech Analytical Technologies Inc.); CP was calculated as N $\times$ 6.25. Composite fecal samples were also analyzed for iNDF, Cr, and $\mathrm{Yb}$ as described above. Total-tract apparent digestibility was calculated based on iNDF concentration in TMR and feces (Schneider and Flatt, 1975). Aliquots of the urine samples were immediately acidified with $2 \mathrm{M} \mathrm{H}_{2} \mathrm{SO}_{4}$ to a $\mathrm{pH}<3.0$, diluted 1:10 with distilled water and stored frozen at $-20^{\circ} \mathrm{C}$. These samples were composited (equal volume based) by cow and period and analyzed for allantoin (Chen et al., 1992), uric acid (Stanbio Uric Acid Kit 1045, Stanbio Laboratory Inc., San Antonio, TX), urea-N (Stanbio Urea Nitrogen Kit 580, Stanbio Laboratory Inc.), and creatinine (Stanbio Creatinine Kit 0400; Stanbio Laboratory Inc.). Another aliquot of the composited urine samples was freeze-dried and analyzed for $\mathrm{N}$ using a Costech ECS 4010 C/N/S elemental analyzer. Daily volume of excreted urine and excretion of $\mathrm{N}$, urinary urea- $\mathrm{N}$, and purine derivatives were estimated as described in Lee et al. (2012). Urinary excretion of purine derivatives was used to estimate duodenal microbial $\mathrm{N}$ flow as described in Hristov et al. (2009). The ratio of purine $\mathrm{N}$ to total $\mathrm{N}$ in bacterial pellets isolated from reticular contents was used in the calculations.

Whole rumen contents samples were collected before and at $2,4,6,8,10,14,18$, and $24 \mathrm{~h}$ after the morning feeding on d 27 and 28 of each experimental period. Samples were collected and processed as described elsewhere (Hristov et al., 2011). Rumen fluid pH was analyzed immediately (pH meter 59000-60 pH Tester, Cole-Parmer Instrument Company, Vernon Hills, IL) and the samples were further processed for analyses of ammonia, VFA, and protozoal counts (Hristov et al., 2011). Aliquots of the whole rumen contents were frozen immediately at $-20^{\circ} \mathrm{C}$. These samples were composited (on an equal wet weight basis) per cow and period and analyzed for bacterial genera and species distribution. The $16 \mathrm{~S}$ rRNA gene V4 variable region PCR primers 515/806 (Caporaso et al., 2011) were used in a single-step 30 cycle PCR using the HotStarTaq Plus Master Mix Kit (Qiagen, Germantown, MD) under the following conditions: $94^{\circ} \mathrm{C}$ for $3 \mathrm{~min}$, followed by 28 cycles (5 cycle used on PCR products) of $94^{\circ} \mathrm{C}$ for $30 \mathrm{~s}, 53^{\circ} \mathrm{C}$ for $40 \mathrm{~s}$ and $72^{\circ} \mathrm{C}$ for $1 \mathrm{~min}$, after which a 
final elongation step at $72^{\circ} \mathrm{C}$ for 5 min was performed. Sequencing was performed at Molecular Research DNA (http://www.mrdnalab.com/, Shallowater, TX) on an Ion Torrent PGM following the manufacturer's guidelines. Sequence data were processed using a proprietary analysis pipeline (MR DNA). In summary, sequences were depleted of barcodes and primers, then sequences $<150$ bp were removed, and sequences with ambiguous base calls and with homopolymer runs exceeding 6 bp were also removed. Sequences were denoised, operational taxonomic units generated, and chimeras removed. Operational taxonomic units were defined by clustering at $3 \%$ divergence $(97 \%$ similarity). Final operational taxonomic units were taxonomically classified using BLASTn against a curated database derived from GreenGenes, RDPII and NCBI (http://www.ncbi.nlm. nih.gov/; DeSantis et al., 2006, http://rdp.cme.msu. $\mathrm{edu}$ ).

Blood samples were collected from the tail vein or artery into heparinized tubes at 6,10 , and $14 \mathrm{~h}$ after feeding on d 24 of each experimental period. Blood samples were immediately centrifuged $(1,500 \times g$ for $15 \mathrm{~min}$ at $4^{\circ} \mathrm{C}$ ) and plasma was stored at $-20^{\circ} \mathrm{C}$ until analyzed. Individual plasma samples were analyzed for Met after extraction with acetonitrile precipitation by HPLC (Shimadzu Prominence, Kyoto, Japan)/MS (AB Sciex API 4000, Concord, Canada) with reference to an internal standard (L-methionine ${ }^{13} \mathrm{C}_{5},{ }^{15} \mathrm{~N}$ ). Aliquots of the plasma samples were composited per cow and period, and the composite samples were analyzed for plasma urea-N (Stanbio Urea Nitrogen Kit 0580, Stanbio Laboratory Inc.).

Milk samples were collected at 2 consecutive milkings (p.m. and a.m.) and 3 consecutive days (d 22, 23, and 24) during each experimental period. Samples were placed in tubes containing 2-bromo-2-nitropropane-1,3diol for analysis of milk fat, true protein, lactose, and MUN (Pennsylvania DHIA, University Park, PA) using infrared spectroscopy (MilkoScan 4000, Foss Electric, Hillerød, Denmark). Morning and evening samples were analyzed separately so milk component concentration and yield could be weighed for a.m. and p.m. milk yields. Aliquots of the milk samples were composited on an equal volume basis per cow and period and processed for analysis of milk FA according to Rico and Harvatine (2013). Briefly, fat was extracted using hexane isopropanol, base transmethylated with sodium methoxide, and FA-methyl esters separated by GC-FID (SP-2560; $100 \mathrm{~m} \times 0.25 \mathrm{~mm}$ i.d. with $0.2-\mu \mathrm{m}$ film thickness; Supelco Inc., Bellefonte, PA).

Cow BW was recorded throughout the trial using AfiFarm 3.04E scale system (S.A.E. Afikim, Rehovot, Israel) while cows exited the milk parlor.

\section{Statistical Analysis}

All data were analyzed using PROC MIXED of SAS (2003, SAS Inst. Inc., Cary, NC). Data, except as stated below, were analyzed by ANOVA Latin square with treatment and period in the model. Square and cow within square were random effects, whereas all others were fixed. Milk production, DMI, feed efficiency, milk composition, FCM, rumen fermentation, and plasma Met data were analyzed as repeated measures assuming an autoregressive(1) covariance structure with treatment, period, sampling time point, and treatment $\times$ sampling time point interaction in the model. In both models the error term was assumed to be normally distributed with mean $=0$ and constant variance. Square and cow within square were the random effects, whereas all others were fixed. Orthogonal and polynomial contrasts were used to evaluate the effects of HMTBa supplementation and application rate (C vs. $\mathrm{Tr}=$ control vs. HMTBa treatments, $\mathrm{L}=$ linear effect of HMTBa, and $\mathrm{Q}=$ quadratic effect of HMTBa). Significant differences were declared at $P \leq 0.05$. Differences at $0.05<P \leq 0.10$ were considered as a trend toward significance. Means are presented, unless indicated otherwise, as least squares means.

\section{RESULTS AND DISCUSSION}

On average, all treatment diets provided $\mathrm{NE}_{\mathrm{L}}$ and MP in excess of the cows' requirements (Table 1). Feed intake and milk production and composition were not affected by HMTBa in this experiment (Table 2). It is noted that DMI was numerically similar (except perhaps for low HMTBa) among treatment, but milk production for the HMTBa treatments decreased numerically by about $1 \mathrm{~kg} / \mathrm{d}$ versus the control. Due to variability in the data, however (and the low number of experimental units), this difference was not statistically significant. Production responses to HMTBa reported in the literature vary significantly among studies. Early data reported positive effects of HMTBa on milk production (Griel et al., 1968) and milk fat concentration and yield (Holter et al., 1972; Lundquist et al., 1983; Huber et al., 1984) in dairy cows. More recent data by Uchida et al. (2003) and Noftsger et al. (2005), however, indicated no effect of HMTBa on milk production and composition. Similarly, Rulquin et al. (2006), Johnson-VanWieringen et al., (2007), and Lapierre et al. (2011) did not find any production effects of HMTBa or a combination of HMTBa and Lys-HCl in cows fed basal diets with 15.3 to $19.5 \%$ CP. Similar lack of effect of HMTBa on DMI and milk yield was recently reported by Baldin 
et al. (2014). On the other hand, a rumen-protected form of HMTBa increased milk production and milk protein yield, without an effect on DMI, in dairy cows fed a diet, for which Met was estimated to be the first limiting AA (Sklan and Tinsky, 1996). Piepenbrink et al. (2004) also observed increased milk yield postpartum with HMTBa supplementation (probably due to a numerical increase in DMI) and a recent study with cows producing about $28 \mathrm{~kg}$ of milk/d reported a $7.5 \%$ increase in milk yield (with no corresponding effect on DMI), $9.7 \%$ increase in milk fat percent, and $63 \%$ increase in serum Met concentration with HMTBa (Wang et al., 2010).
Intake of nutrients during the fecal and urine collection periods was not affected by treatment, but subtle trends were present in total-tract apparent digestibility; HMTBa tended to linearly decrease $(P=$ $0.08) \mathrm{ADF}$ and quadratically decreased $\mathrm{CP}$ and starch digestibilities $(P=0.01$ and 0.02 , respectively; Table $3)$. Digestibility of ADF tended to decrease by about $2 \%$ by the highest level of HMTBa and that of CP and starch decreased 5 and $1 \%$, respectively, by the medium HMTBa. Treatment had no effect on ruminal (true) degradability of $\mathrm{DM}(59.6 \pm 0.97 ; P>0.18)$, $\mathrm{OM}(62.5 \pm 0.91 ; P>0.22), \mathrm{CP}$, and NDF (data not shown in tables). In contrast, Noftsger et al. (2005)

Table 1. Composition of the basal diet fed in the trial and balance of key nutrients (all diets had the same ingredient and chemical composition)

\begin{tabular}{|c|c|c|c|c|}
\hline \multirow[b]{2}{*}{ Item } & \multicolumn{4}{|c|}{$\operatorname{Diet}^{1}$} \\
\hline & Control & Low & Medium & High \\
\hline \multicolumn{5}{|l|}{ Ingredient, $\%$ of $\mathrm{DM}$} \\
\hline Corn silage $^{2}$ & \multicolumn{4}{|c|}{46.1} \\
\hline Grass hay $^{3}$ & \multicolumn{4}{|c|}{8.4} \\
\hline Corn grain, ground & \multicolumn{4}{|c|}{10.7} \\
\hline Soybean mean, $48 \% \mathrm{CP}$ & \multicolumn{4}{|c|}{7.0} \\
\hline Canola meal & \multicolumn{4}{|c|}{6.9} \\
\hline Soybean seeds, whole, heated & \multicolumn{4}{|c|}{6.1} \\
\hline Cottonseed hulls & \multicolumn{4}{|c|}{5.4} \\
\hline Molasses $^{4}$ & \multicolumn{4}{|c|}{4.3} \\
\hline Mineral and vitamin premix ${ }^{5}$ & \multicolumn{4}{|c|}{2.83} \\
\hline HMTBa premix $^{6}$ & \multicolumn{4}{|c|}{1.5} \\
\hline Limestone & \multicolumn{4}{|c|}{0.35} \\
\hline Urea & \multicolumn{4}{|c|}{0.25} \\
\hline Salt & \multicolumn{4}{|c|}{0.17} \\
\hline \multicolumn{5}{|l|}{ Analyzed composition, ${ }^{7} \%$ of DM } \\
\hline $\mathrm{OM}$ & \multicolumn{4}{|c|}{$93.6 \pm 0.10$} \\
\hline $\mathrm{CP}$ & \multicolumn{4}{|c|}{$15.9 \pm 0.34$} \\
\hline NDF & \multicolumn{4}{|c|}{$33.0 \pm 0.83$} \\
\hline $\mathrm{ADF}$ & \multicolumn{4}{|c|}{$20.4 \pm 0.38$} \\
\hline Ether extract & \multicolumn{4}{|c|}{$2.9 \pm 0.05$} \\
\hline $\mathrm{Ca}$ & \multicolumn{4}{|c|}{$0.79 \pm 0.08$} \\
\hline $\mathrm{P}$ & \multicolumn{4}{|c|}{$0.39 \pm 0.01$} \\
\hline & \multicolumn{4}{|c|}{$1.63 \pm 0.01$} \\
\hline \multicolumn{5}{|l|}{ Nutrient balance $^{8}$} \\
\hline $\mathrm{NE}_{\mathrm{L}}, \mathrm{Mcal} / \mathrm{d}$ & 2.5 & 1.5 & 4.2 & 2.7 \\
\hline $\mathrm{RDP}, \mathrm{g} / \mathrm{d}$ & 40 & 40 & 40 & 41 \\
\hline $\mathrm{MP}, \mathrm{g} / \mathrm{d}$ & 106 & 78 & 192 & 146 \\
\hline
\end{tabular}

${ }^{1}$ Control $=0 \%$ (diet, DM basis) 2-hydroxy-4-methylthio-butanoic acid (HMTBa; as Alimet, Novus International Inc., St. Charles, MO); low $=0.05 \%$ HMTBa; medium $=0.10 \%$ HMTBa; high $=0.15 \%$ HMTBa.

${ }^{2}$ Corn silage was $39.0 \% \mathrm{DM}$ and (DM basis): $7.6 \% \mathrm{CP}$ and $36.8 \% \mathrm{NDF}$.

${ }^{3}$ Grass hay was $82.6 \%$ DM and (DM basis): $10.8 \% \mathrm{CP}$ and $70.1 \%$ NDF.

${ }^{4}$ Molasses (Westway Feed Products, Tomball, TX) contained (DM basis): $3.9 \% \mathrm{CP}$ and $66 \%$ total sugar.

${ }^{5}$ The premix contained (\%, as-is basis): trace mineral mix, $0.86 ; \mathrm{MgO}(56 \% \mathrm{Mg}), 8.0 ; \mathrm{NaCl}, 6.4$; vitamin $\mathrm{ADE}$ premix, 0.48; limestone, 37.2; selenium premix, 0.07; and dry corn distillers grains with solubles, 46.7. Ca, 14.1\%; P, 0.39\%; Mg, 4.59\%; K, 0.44\%; S, 0.39\%; Se, $6.91 \mathrm{mg} / \mathrm{kg} ; \mathrm{Cu}, 362 \mathrm{mg} / \mathrm{kg} ; \mathrm{Zn}, 1,085 \mathrm{mg} / \mathrm{kg} ; \mathrm{Fe}, 186$ $\mathrm{mg} / \mathrm{kg}$, vitamin A, 276,717 IU/kg; vitamin D, 75,000 IU $/ \mathrm{kg}$; and vitamin E, 1,983 IU $/ \mathrm{kg}$.

${ }^{6}$ Top-dressed and contained: $100 \%$ fine ground corn (control) or $3.33 \%$ HMTBa, $6.67 \%$ HMTBa, or $10 \%$ HMTBa replacing fine ground corn for low, medium, or high, respectively.

${ }^{7}$ Four $( \pm \mathrm{SE})$ composite samples were analyzed (Cumberland Valley Analytical Services, Maugansville, MD). $\mathrm{NE}_{\mathrm{L}}$ was calculated based on the chemical composition of the diets (http://www.foragelab.com/Resources/ Report-Calculations; accessed June 23, 2014).

${ }^{8}$ Averaged estimates based on NRC (2001) using actual DMI, milk yield, milk composition, and BW of the cows (last week of each experimental period). 
Table 2. Effect of 2-hydroxy-4-methylthio-butanoic acid (HMTBa) on DMI, milk yield and composition, and BW in dairy cows

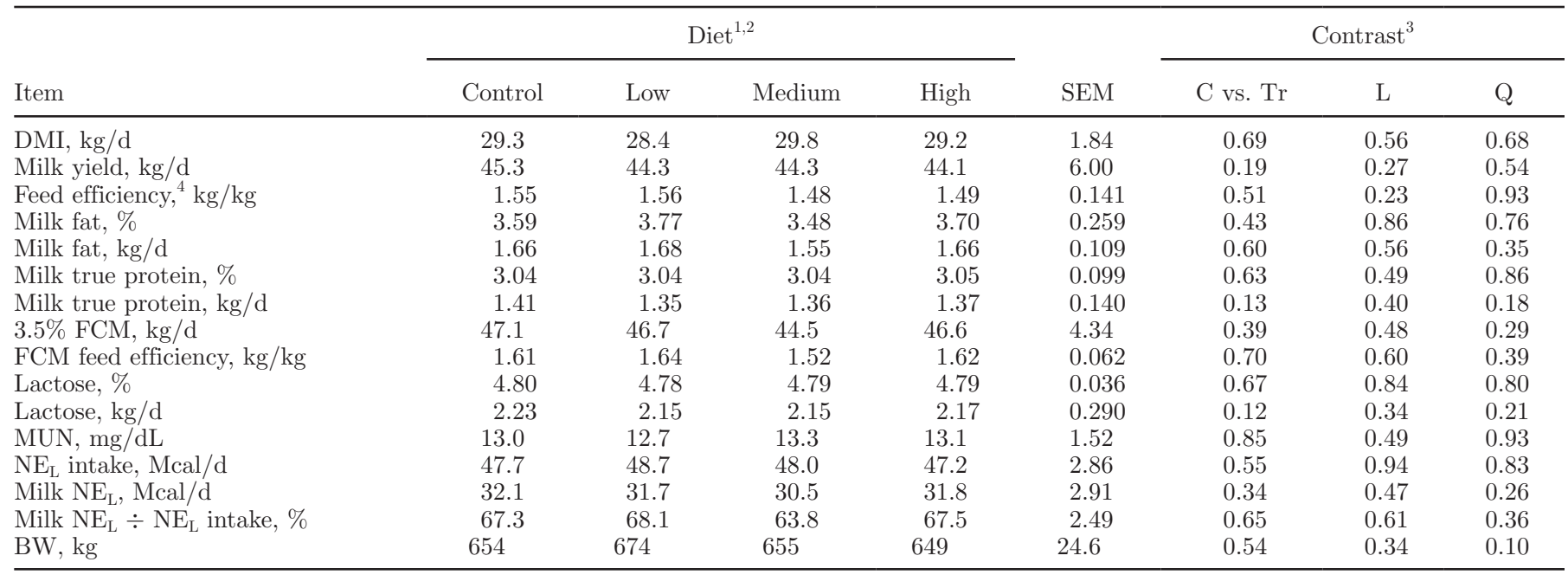

${ }^{1}$ Control $=0 \%$ (diet DM basis) HMTBa (as Alimet, Novus International Inc., St. Charles, MO); low =0.05\% HMTBa; medium $=0.10 \%$ HMTBa; high $=0.15 \%$ HMTBa.

${ }^{2}$ Least squares means; production data, $\mathrm{n}=216$ to 224 ; milk composition, $\mathrm{n}=96$; $\mathrm{BW}, \mathrm{n}=32$ ( $\mathrm{n}$ represents number of observations used in the statistical analysis).

${ }^{3} \mathrm{C}$ vs. $\mathrm{Tr}=$ control vs. HMTBa treatments; $\mathrm{L}=$ linear effect of HMTBa; $\mathrm{Q}=$ quadratic effect of HMTBa.

${ }^{4}$ Milk yield/DMI.

reported increased ruminal OM and NDF digestibility as a result of HMTBa supplementation of the diet. In an earlier study, however, HMTBa had no effect on nutrient degradability in continuous culture fermenters (Vazquez-Añon et al., 2001). The effects observed in the current experiment were likely due to a combination of numerically increased DMI and increased fecal $\mathrm{N}$ excretion with the medium and high HMTBa treat- ments (compared with the control) as well as natural variability in the data.

Nitrogen secretion and excretion, urinary purine derivatives excretion, and rumen microbial protein synthesis estimates are shown in Table 4. Most variables were not affected by HMTBa. As \% of $\mathrm{N}$ intake, urinary $\mathrm{N}$ excretion was increased $(P=0.04$; a quadratic response) by HMTBa and so was absolute and relative

Table 3. Effect of 2-hydroxy-4-methylthio-butanoic acid (HMTBa) on intake and total-tract apparent digestibility of nutrients in dairy cows

\begin{tabular}{|c|c|c|c|c|c|c|c|c|}
\hline \multirow[b]{2}{*}{ Item } & \multicolumn{4}{|c|}{$\operatorname{Diet}^{1,2}$} & \multirow[b]{2}{*}{ SEM } & \multicolumn{3}{|c|}{ Contrast $^{3}$} \\
\hline & Control & Low & Medium & High & & $\mathrm{C}$ vs. $\mathrm{Tr}$ & $\mathrm{L}$ & $\mathrm{Q}$ \\
\hline DM & 29.0 & 28.4 & 29.7 & 29.2 & 1.68 & 0.91 & 0.21 & 0.69 \\
\hline $\mathrm{OM}$ & 27.2 & 26.6 & 27.7 & 27.4 & 1.58 & 0.91 & 0.21 & 0.69 \\
\hline $\mathrm{NDF}$ & 9.6 & 9.4 & 9.8 & 9.6 & 0.55 & 0.99 & 0.25 & 0.69 \\
\hline $\mathrm{ADF}$ & 5.9 & 7.8 & 6.1 & 6.0 & 0.34 & 0.99 & 0.25 & 0.68 \\
\hline \multicolumn{9}{|c|}{ Apparent total-tract digestibility, \% } \\
\hline DM & 68.0 & 68.1 & 66.9 & 67.7 & 0.38 & 0.23 & 0.17 & 0.24 \\
\hline $\mathrm{OM}$ & 69.2 & 69.2 & 68.2 & 68.9 & 0.39 & 0.26 & 0.20 & 0.29 \\
\hline $\mathrm{NDF}$ & 48.6 & 49.0 & 47.7 & 49.1 & 0.56 & 0.98 & 0.92 & 0.39 \\
\hline $\mathrm{ADF}$ & 41.2 & 41.1 & 40.8 & 40.3 & 0.64 & 0.31 & 0.08 & 0.52 \\
\hline $\mathrm{CP}$ & 69.6 & 68.4 & 66.1 & 68.6 & 0.85 & 0.02 & 0.09 & 0.01 \\
\hline Starch & 96.4 & 95.9 & 95.5 & 96.5 & 0.39 & 0.19 & 0.99 & 0.02 \\
\hline
\end{tabular}

${ }^{1}$ Control $=0 \%$ (diet DM basis) HMTBa (as Alimet, Novus International Inc., St. Charles, MO); low =0.05\% HMTBa; medium $=0.10 \%$ HMTBa; high $=0.15 \%$ HMTBa.

${ }^{2}$ Least squares means; $\mathrm{n}=32$ ( $\mathrm{n}$ represents number of observations used in the statistical analysis).

${ }^{3} \mathrm{C}$ vs. $\mathrm{Tr}=$ control vs. HMTBa treatments; $\mathrm{L}=$ linear effect of HMTBa; $\mathrm{Q}=$ quadratic effect of HMTBa.

${ }^{4}$ Intake during the digestibility data collection periods. 
Table 4. Effect of 2-hydroxy-4-methylthio-butanoic acid (HMTBa) on $\mathrm{N}$ intake, $\mathrm{N}$ secretion in milk, urinary and fecal $\mathrm{N}$ excretion, urinary purine derivative $(\mathrm{PD})$ excretion, and blood plasma urea $\mathrm{N}(\mathrm{PUN})$ concentration in dairy cows

\begin{tabular}{|c|c|c|c|c|c|c|c|c|}
\hline \multirow[b]{2}{*}{ Item } & \multicolumn{4}{|c|}{ Diet $^{1}$} & \multirow[b]{2}{*}{ SEM } & \multicolumn{3}{|c|}{ Contrast $^{2}$} \\
\hline & Control & Low & Medium & High & & $\mathrm{C}$ vs. $\mathrm{Tr}$ & $\mathrm{L}$ & Q \\
\hline Urine $\mathrm{N}, \mathrm{kg} / \mathrm{d}$ & 0.163 & 0.168 & 0.175 & 0.156 & 0.0138 & 0.69 & 0.67 & 0.11 \\
\hline As $\%$ of $\mathrm{N}$ intake & 22.3 & 23.5 & 23.6 & 20.7 & 0.93 & 0.80 & 0.26 & 0.04 \\
\hline Urinary urea $\mathrm{N}, \mathrm{kg} / \mathrm{d}$ & 0.104 & 0.103 & 0.106 & 0.101 & 0.0074 & 0.93 & 0.80 & 0.62 \\
\hline As $\%$ of $\mathrm{N}$ intake & 14.3 & 14.5 & 14.2 & 13.5 & 0.43 & 0.72 & 0.25 & 0.36 \\
\hline Fecal and urine $\mathrm{N}, \mathrm{kg} / \mathrm{d}$ & 0.386 & 0.394 & 0.429 & 0.387 & 0.0227 & 0.13 & 0.38 & 0.02 \\
\hline As $\%$ of $\mathrm{N}$ intake & 52.7 & 55.1 & 57.5 & 52.1 & 1.06 & 0.13 & 0.92 & 0.004 \\
\hline Milk protein $\mathrm{N}^{4} \mathrm{~kg} / \mathrm{d}$ & 0.220 & 0.212 & 0.213 & 0.215 & 0.0218 & 0.12 & 0.38 & 0.17 \\
\hline As $\% \mathrm{~N}$ intake & 29.9 & 29.5 & 28.3 & 29.2 & 1.32 & 0.14 & 0.16 & 0.24 \\
\hline $\mathrm{N}$ secreted or excreted in milk protein and excreta, $\mathrm{kg} / \mathrm{d}$ & 0.607 & 0.607 & 0.642 & 0.602 & 0.0435 & 0.37 & 0.60 & 0.06 \\
\hline As \% of $\mathrm{N}$ intake & 82.6 & 84.6 & 85.9 & 81.2 & 1.45 & 0.33 & 0.59 & 0.009 \\
\hline \multicolumn{9}{|l|}{ Excretion of $\mathrm{PD}, \mathrm{mmol} / \mathrm{d}$} \\
\hline $\mathrm{PUN}, \mathrm{mg} / \mathrm{dL}$ & 11.8 & 10.5 & 11.3 & 11.5 & 0.61 & 0.10 & 0.90 & 0.05 \\
\hline
\end{tabular}

${ }^{1}$ Control $=0 \%$ (diet, DM basis) HMTBa (as Alimet, Novus International Inc., St. Charles, MO); low $=0.05 \%$ HMTBa; medium $=0.10 \%$ HMTBa; high $=0.15 \%$ HMTBa.

${ }^{2}$ Least squares means; $\mathrm{n}=32$ ( $\mathrm{n}$ represents number of observations used in the statistical analysis).

${ }^{3} \mathrm{C}$ vs. $\mathrm{Tr}=$ control vs. HMTBa treatments; $\mathrm{L}=$ linear effect of HMTBa; $\mathrm{Q}=$ quadratic effect of HMTBa.

${ }^{4}$ Milk true protein $\times 6.38$.

${ }^{5}$ Based on excretion of urinary purine derivatives.

fecal $\mathrm{N}$ excretion $(P \leq 0.03)$. This resulted in increased $(P \leq 0.02)$ total fecal and urinary $\mathrm{N}$ excretion with the low and medium HMTBa levels compared with the control. Except for an inconsequential trend of a linear decrease $(P=0.09)$ in urinary uric acid excretion, treatment had no effect on urinary purine derivative excretion and the estimated rumen microbial protein synthesis. Plasma urea $\mathrm{N}$ was quadratically decreased $(P=0.05)$ by the low HMTBa application level, which was in disagreement with the urine and fecal $\mathrm{N}$ excretion data. Previous studies have not detected differences in estimated excretion of urinary or fecal $\mathrm{N}$

Table 5. Effect of 2-hydroxy-4-methylthio-butanoic acid (HMTBa) on rumen fermentation in dairy cows

\begin{tabular}{|c|c|c|c|c|c|c|c|c|}
\hline Item & \multicolumn{4}{|c|}{$\operatorname{Diet}^{1,2}$} & SEM & \multicolumn{3}{|c|}{ Contrast $^{3}$} \\
\hline $\mathrm{pH}$ & 6.00 & 5.97 & 5.94 & 5.93 & 0.050 & 0.36 & 0.31 & 0.86 \\
\hline Protozoa, ${ }^{4} \times 10^{4} / \mathrm{mL}$ & 144 & 144 & 145 & 143 & 19.7 & 0.79 & 0.91 & 0.86 \\
\hline Total VFA, mM & 128.3 & 125.8 & 124.1 & 125.8 & 1.75 & 0.15 & 0.25 & 0.26 \\
\hline Acetate & 79.1 & 77.1 & 77.4 & 78.9 & 1.24 & 0.31 & 0.96 & 0.11 \\
\hline Isovalerate & 1.80 & 1.79 & 1.72 & 1.85 & 0.058 & 0.77 & 0.75 & 0.14 \\
\hline Valerate & 2.25 & 2.17 & 2.07 & 2.12 & 0.050 & 0.01 & 0.02 & 0.16 \\
\hline Ac:Pr ratio & 2.86 & 2.87 & 2.90 & 3.00 & 0.082 & 0.27 & 0.05 & 0.42 \\
\hline
\end{tabular}

${ }^{1}$ Control $=0 \%$ (diet DM basis) HMTBa (as Alimet, Novus International Inc., St. Charles, MO); low $=0.05 \%$ HMTBa; medium $=0.10 \%$ HMTBa; high $=0.15 \%$ HMTBa.

${ }^{2}$ Least squares means; $\mathrm{n}=288$ ( $\mathrm{n}$ represents number of observations used in the statistical analysis).

${ }^{3} \mathrm{C}$ vs. $\mathrm{Tr}=$ control vs. HMTBa treatments; $\mathrm{L}=$ linear effect of HMTBa; $\mathrm{Q}=$ quadratic effect of HMTBa.

${ }^{4} \log$-transformed data were used for the statistical analysis. 


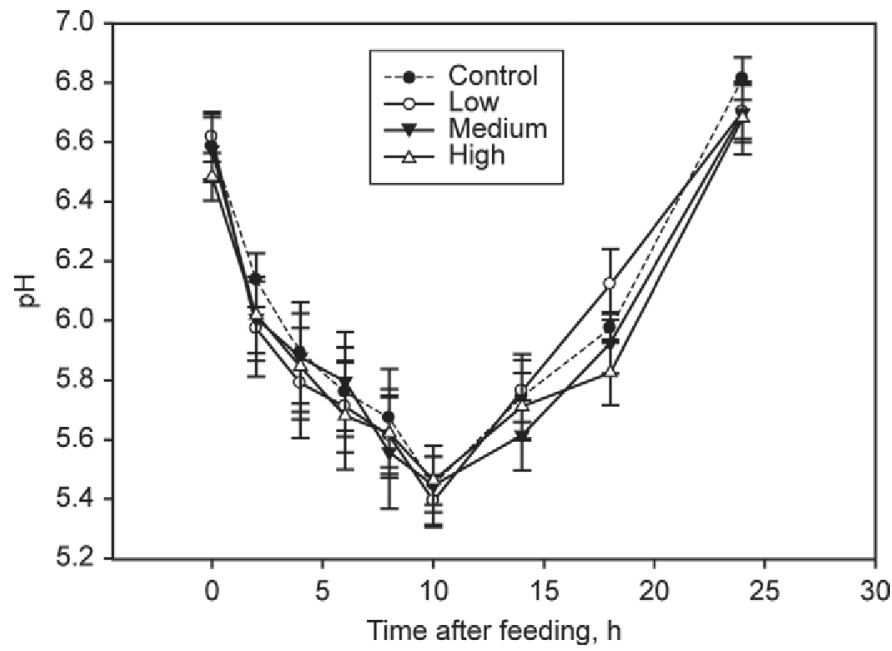

Figure 1. Effect of 2-hydroxy-4-methylthio-butanoic acid $(\mathrm{HMTBa})$ on rumen $\mathrm{pH}$ in dairy cows $($ mean $\pm \mathrm{SE}$ ); control $=0 \%$ (diet DM basis) HMTBa (as Alimet, Novus International Inc., St. Charles, MO); low $=0.05 \%$ HMTBa; medium $=0.10 \%$ HMTBa; high $=0.15 \%$ HMTBa. For statistical analysis of the data, see Table 5 .

when HMTBa was fed to cows in crossover (Chen et al., 2011) or continuous design studies (St-Pierre and Sylvester, 2005).

Rumen fermentation data, concentration of microbial $\mathrm{N}$ in reticular contents, and microbial $\mathrm{N}$ production data are shown in Tables 5 and 6 . Treatment had no effect of rumen fermentation, except that butyrate and valerate concentrations decreased $(P \leq 0.03)$ and propionate tended to decrease $(P=0.08)$ linearly, which resulted in increased $(P=0.05)$ acetate:propionate ratio with HMTBa supplementation. Rumen fluid $\mathrm{pH}$ was not affected by treatment at any sampling point during the feeding cycle (Figure 1). The largest numerical difference in $\mathrm{pH}$ among treatments was observed at $18 \mathrm{~h}(5.97,6.12,5.93$, and 5.82 for control, low, medium, and high, respectively; $P \geq 0.33$ ). Based on the ${ }^{15} \mathrm{~N}$ data, no difference was observed in the proportion of microbial $\mathrm{N}$ in the fractions of reticular content due to treatment (Table 6). Numerical differences $(P=0.14$ to 0.17$)$ were found in the concentration of microbial $\mathrm{N}$ in large particles and whole reticular contents, which did not reach statistical significance. Microbial $\mathrm{N}$ production in the rumen increased linearly $(P=0.04)$ with HMTBa supplementation. Microbial $\mathrm{N}$ outflow from the rumen was on average about $27 \%$ higher when estimated based on excretion of urinary purine derivatives compared with the estimates based on reticular sampling. The urinary purine derivative method produced a larger variability in the estimates $(\mathrm{CV}=0.22)$ than the reticular sampling method $(\mathrm{CV}$ $=0.16)$, which contributed to the lack of statistically significant effect with the former method. Similar to the current study, the urinary purine derivatives method produced about $21 \%$ higher estimates for microbial protein synthesis compared with a duodenal sampling method in a previous study (Hristov et al., 2005b). In a continuous culture study, Vazquez-Añon et al. (2001) reported no effect of HMTBa applied at up to $1.43 \%$ (feed DM basis) on VFA concentrations and medium $\mathrm{pH}$ but observed a quadratic increase in bacterial $\mathrm{N}$

Table 6. Effect of 2-hydroxy-4-methylthio-butanoic acid (HMTBa) on $\delta^{15} \mathrm{~N}$ of bacterial and reticular contents $\mathrm{N}$, concentration of microbial $\mathrm{N}$ in reticular contents, and estimated microbial $\mathrm{N}$ production in the rumen and contribution of microbial $\mathrm{N}$ to milk protein in dairy cows

\begin{tabular}{|c|c|c|c|c|c|c|c|c|}
\hline \multirow[b]{2}{*}{ Item } & \multicolumn{4}{|c|}{$\operatorname{Diet}^{1,2}$} & \multirow[b]{2}{*}{ SEM } & \multicolumn{3}{|c|}{ Contrast $^{3}$} \\
\hline & Control & Low & Medium & High & & C vs. $\operatorname{Tr}$ & $\mathrm{L}$ & Q \\
\hline \multicolumn{9}{|l|}{$\delta^{15} \mathrm{~N}, \%$} \\
\hline Fluid & 116 & 113 & 112 & 115 & 6.08 & 0.64 & 0.84 & 0.58 \\
\hline Small particles & 81.0 & 79.3 & 80.2 & 82.1 & 3.62 & 0.85 & 0.68 & 0.42 \\
\hline Milk protein & 49.4 & 49.4 & 48.2 & 49.2 & 2.44 & 0.76 & 0.76 & 0.72 \\
\hline \multicolumn{9}{|l|}{ Microbial $\mathrm{N}, \mathrm{mg} / \mathrm{g}$ of $\mathrm{DM}$} \\
\hline Ruminal fluid & 19.7 & 19.9 & 19.5 & 20.0 & 1.07 & 0.97 & 0.91 & 0.76 \\
\hline Small particles & 38.5 & 39.8 & 39.9 & 39.4 & 0.95 & 0.17 & 0.40 & 0.20 \\
\hline Large particles & 14.3 & 16.0 & 15.7 & 16.7 & 1.11 & 0.14 & 0.14 & 0.72 \\
\hline Whole contents & 21.5 & 22.3 & 22.1 & 22.9 & 0.88 & 0.21 & 0.17 & 0.95 \\
\hline Microbial N production, $\mathrm{g} / \mathrm{d}$ & 365 & 365 & 390 & 391 & 22.3 & 0.19 & 0.04 & 0.95 \\
\hline
\end{tabular}

${ }^{1}$ Control $=0 \%$ (diet DM basis) HMTBa (as Alimet, Novus International Inc., St. Charles, MO); low $=0.05 \%$ HMTBa; medium $=0.10 \%$ HMTBa; high $=0.15 \%$ HMTBa.

${ }^{2}$ Least squares means; $\mathrm{n}=32$ ( $\mathrm{n}$ represents number of observations used in the statistical analysis).

${ }^{3} \mathrm{C}$ vs. Tr $=$ control vs. HMTBa treatments; $\mathrm{L}=$ linear effect of HMTBa; $\mathrm{Q}=$ quadratic effect of HMTBa.

${ }^{4}$ Found as: $\delta^{15} \mathrm{~N}$ of milk protein $\div \delta^{15} \mathrm{~N}$ of rumen bacterial protein. 
Table 7. Effect of 2-hydroxy-4-methylthio-butanoic acid (HMTBa) on rumen bacterial genus composition (as percentage ${ }^{1}$ of total isolates) in dairy cows

\begin{tabular}{|c|c|c|c|c|c|c|c|c|}
\hline \multirow[b]{2}{*}{ Item } & \multicolumn{4}{|c|}{$\operatorname{Diet}^{2,3}$} & \multirow[b]{2}{*}{ SEM } & \multicolumn{3}{|c|}{ Contrast $^{4}$} \\
\hline & Control & Low & Medium & High & & $\mathrm{C}$ vs. $\mathrm{Tr}$ & $\mathrm{L}$ & $\mathrm{Q}$ \\
\hline Tannerella & 6.33 & 6.84 & 6.49 & 7.19 & 1.054 & 0.29 & 0.23 & 0.81 \\
\hline Oscillospira & 5.66 & 6.24 & 6.04 & 7.29 & 0.732 & 0.27 & 0.13 & 0.61 \\
\hline Parabacteroides & 5.43 & 5.51 & 5.05 & 5.98 & 0.953 & 0.87 & 0.57 & 0.37 \\
\hline Bacteroides & 3.09 & 3.38 & 3.26 & 3.18 & 0.187 & 0.45 & 0.88 & 0.38 \\
\hline Clostridium & 3.04 & 3.26 & 2.96 & 3.29 & 0.300 & 0.72 & 0.75 & 0.87 \\
\hline Acidaminococcus & 2.96 & 3.06 & 2.75 & 2.30 & 0.759 & 0.46 & 0.09 & 0.35 \\
\hline Butyrivibrio & 1.86 & 1.95 & 2.08 & 1.75 & 0.160 & 0.74 & 0.79 & 0.24 \\
\hline Alistipes & 1.88 & 1.84 & 1.74 & 1.94 & 0.316 & 0.77 & 0.90 & 0.34 \\
\hline Roseburia & 1.83 & 1.72 & 1.69 & 1.74 & 0.170 & 0.56 & 0.69 & 0.63 \\
\hline Fibrobacter & 1.59 & 1.42 & 1.41 & 1.55 & 0.259 & 0.70 & 0.91 & 0.60 \\
\hline Selenomonas & 0.63 & 0.82 & 0.55 & 0.70 & 0.167 & 0.67 & 0.89 & 0.85 \\
\hline Blautia & 0.56 & 0.63 & 0.68 & 0.58 & 0.071 & 0.49 & 0.78 & 0.34 \\
\hline Aggregatibacter & 0.16 & 0.52 & 0.59 & 0.75 & 0.491 & 0.21 & 0.19 & 0.75 \\
\hline Fecalibacterium & 0.35 & 0.50 & 0.45 & 0.57 & 0.068 & 0.05 & 0.04 & 0.85 \\
\hline Hemophilus & 0.47 & 0.18 & 0.62 & 0.38 & 0.135 & 0.69 & 0.79 & 0.88 \\
\hline Anaerotruncus & 0.34 & 0.42 & 0.40 & 0.44 & 0.049 & 0.14 & 0.17 & 0.64 \\
\hline Streptococcus & 0.32 & 0.39 & 0.40 & 0.37 & 0.044 & 0.19 & 0.38 & 0.27 \\
\hline
\end{tabular}

${ }^{1}$ The percentage represents the percentage of the total sequences analyzed within the sample.

${ }^{2}$ Control $=0 \%$ (diet DM basis) HMTBa (as Alimet, Novus International Inc., St. Charles, MO); low =0.05\% HMTBa; medium $=0.10 \%$ HMTBa; high $=0.15 \%$ HMTBa.

${ }^{3}$ Least squares means; $\mathrm{n}=32$ ( $\mathrm{n}$ represents number of observations used in the statistical analysis).

${ }^{4} \mathrm{C}$ vs. $\mathrm{Tr}=$ control vs. HMTBa treatments; $\mathrm{L}=$ linear effect of HMTBa; $\mathrm{Q}=$ quadratic effect of HMTBa.

outflow and efficiency of $\mathrm{N}$ synthesis. Although in vitro and continuous culture data should be interpreted with caution (Hristov et al., 2012), results from the current study are in support of those reported by VazquezAñon et al. (2001) and suggest a subtle, stimulatory effect of HMTBa on the ruminal microbes. To act on the rumen microbes, HMTBa has to be metabolized, at least partially, in the rumen. In vivo and in vitro studies have shown 40 to $50 \%$ ruminal escape of HMTBa (Koenig et al., 1999; Vazquez-Añon et al., 2001; Koenig et al., 2002), which means a significant amount of HMTBa is metabolized in the rumen. A much lower escape rate was reported by Noftsger et al. (2005), although potential absorption through the rumen wall was not accounted for in that study. The exact mode of action of HMTBa in the rumen is not clear, but is probably related to the specific stimulatory effect of AA and peptides on microbial growth, particularly of some cellulolytic bacteria (Cotta and Russell, 1982; Russell, 1993; Van Kessel and Russell, 1996). Although the latter data are from in vitro studies, they are in line with some reports for increased fiber degradation with
HMTBa in vivo (Noftsger et al., 2005). The effect of HMTBa on some VFA in the current study is difficult to explain. Concentration of butyrate, for example, was decreased, but the prevalence of Butyrivibrio spp. (or Butyrivibrio fibrisolvens; see later discussions) was not affected by HMTBa. Metabolites of Met-analogs may alter rumen VFA molar proportions, as suggested for HMBi by Martin et al. (2013), but most studies showed no effect of HMTBa (or HMBi) on rumen VFA concentrations (Vazquez-Añon et al., 2001; Noftsger et al., 2005; Martin et al., 2013).

In the current study, treatment had no effect on ruminal bacterial genus and species distribution (Tables 7 and 8, respectively). The percentage of genus Fecalibacterium of the total sequences analyzed within a sample was linearly increased $(P=0.04)$, whereas the percentage of Acidaminococcus tended to be decreased $(P=$ 0.09 ) and that of Eubacterium was decreased quadratically $(P=0.04)$ by HMTBa. Of the individual bacterial species, Prevotella loescheii and Prevotella oralis were increased or tended to be increased $(P \leq 0.08)$ by HMTBa, compared with the control. No specific effect of 
Table 8. Effect of 2-hydroxy-4-methylthio-butanoic acid (HMTBa) on rumen bacterial species composition (as percentage ${ }^{1}$ of total isolates) in dairy cows

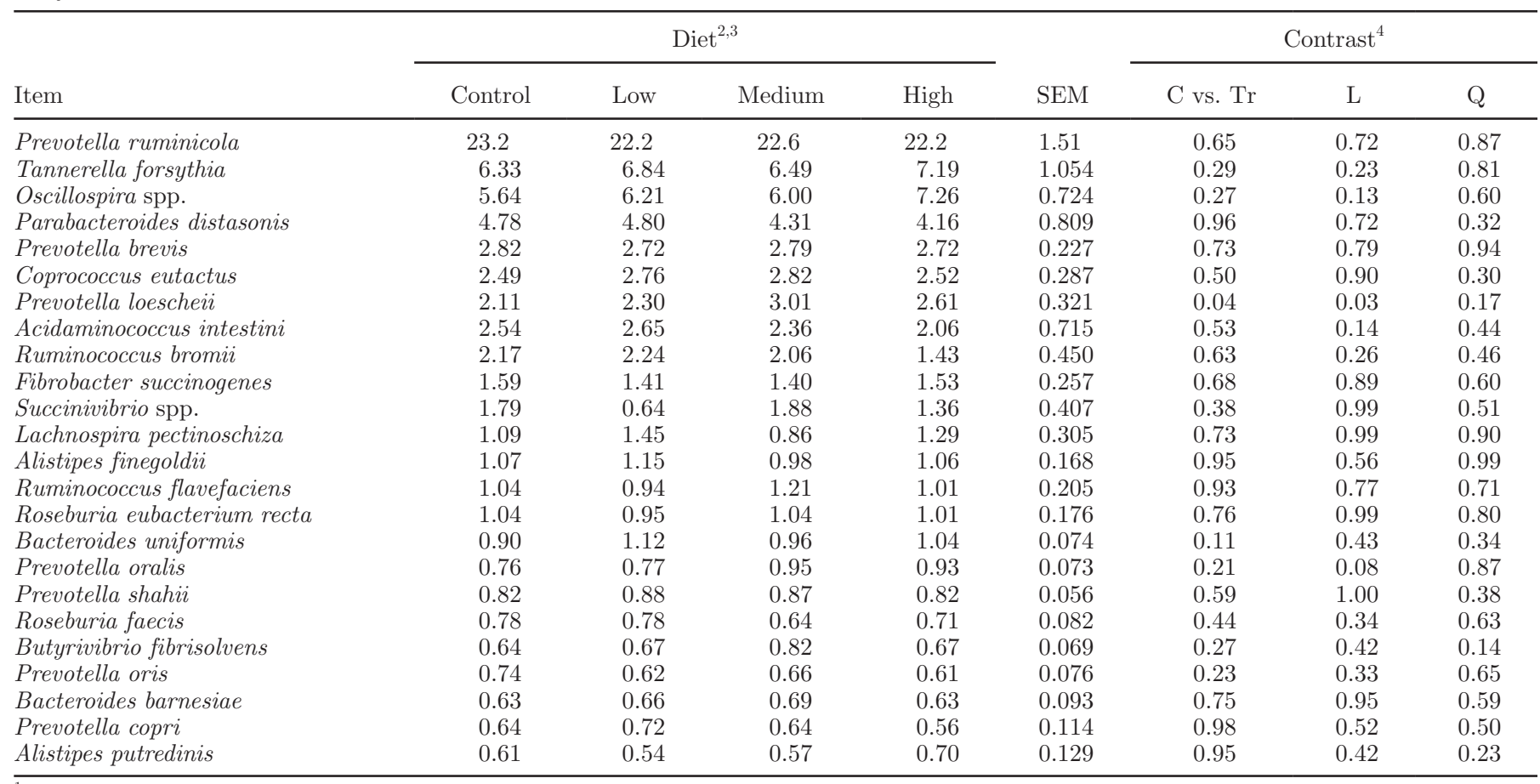

${ }^{1}$ The percentage represents the percentage of the total sequences analyzed within the sample.

${ }^{2}$ Control $=0 \%$ (diet DM basis) HMTBa (as Alimet, Novus International Inc., St. Charles, MO); low $=0.05 \%$ HMTBa; medium $=0.10 \%$ HMTBa; high $=0.15 \%$ HMTBa.

${ }^{3}$ Least squares means; $\mathrm{n}=32$ ( $\mathrm{n}$ represents number of observations used in the statistical analysis).

${ }^{4} \mathrm{C}$ vs. $\mathrm{Tr}=$ control vs. HMTBa treatments; $\mathrm{L}=$ linear effect of HMTBa; $\mathrm{Q}=$ quadratic effect of HMTBa.

HMTBa on the common rumen cellulolytic species was observed in this experiment. Similar lack of effect of HMTBa on the structure of the rumen bacterial community was reported by Noftsger et al. (2003) in continuous culture. These authors suggested that perhaps protozoa are affected by HMTBa supplementation, but a latter study from the same group found no effect of HMTBa (or its isopropyl ester, HMBi) on ruminal protozoal genera distribution (Karnati et al., 2007). A more recent study, however, reported increased abundance of 2 important cellulolytic bacteria (Fibrobacter succinogenes and Ruminococcus flavefaciens) in dairy cows receiving HMTBa (and $\mathrm{HMBi}$ ), but this had no consequential effects on ruminal fermentation, cellulolytic activities, or corn silage in situ NDF degradability in dry cows (Martin et al., 2013).

With a few notable exceptions, HMTBa had no effect on milk FA composition in the current study (Table 9). Supplementation of the basal diet with HMTBa tended to decrease or decreased linearly $(P=0.06$ and 0.04 , respectively) the concentration of $4: 0$ and $6: 0$ and increased $(P \leq 0.01)$ concentrations of $15: 0$ and 17:0 in milk fat. Treatment also slightly decreased trans- 6,8
18:1 $(P=0.02)$ and trans-10 18:1 $(P=0.04)$. The yield of 15:0 was quadratically increased $(P=0.009)$ by HMTBa. A similar increase in 15:0 concentration in milk fat was reported for HMTBa by Rulquin et al. (2006). The so-called odd- and branched-chain FA in milk fat, which include 15:0 and 17:0, are found in microbial lipids (Keeney et al., 1962) and are also synthesized from propionate in the adipose and mammary tissues (Vlaeminck et al., 2006). Considered predominantly of microbial origin, these FA have been proposed as biomarkers of microbial synthesis or methane production in the rumen (Vlaeminck et al., 2006; Dijkstra et al., 2011; Fievez et al., 2012). Although the concept has been questioned and needs verification under various dietary regimens (Dewhurst et al., 2007; Mohammed et al., 2011; French et al., 2012), the trends observed for milk FA in the current study are in agreement with the trends in microbial $\mathrm{N}$ concentration in reticular contents and microbial $\mathrm{N}$ outflow from the rumen. The decrease in trans-10, 18:1 is consistent with beneficial effects on milk fat yield as this isomer is associated with the alternate biohydrogenation pathway and milk fat depression. However, the basal diet in the current 
Table 9. Effect of 2-hydroxy-4-methylthio-butanoic acid (HMTBa) on milk fatty acid concentration in total milk fat or yield

\begin{tabular}{|c|c|c|c|c|c|c|c|c|}
\hline Item & \multicolumn{4}{|c|}{$\operatorname{Diet}^{1,2}$} & SEM & \multicolumn{3}{|c|}{ Contrast $^{3}$} \\
\hline \multicolumn{9}{|c|}{ Fatty acid concentration, $\mathrm{g} / 100 \mathrm{~g}$} \\
\hline $6: 0$ & 2.58 & 2.51 & 2.56 & 2.49 & 0.053 & 0.029 & 0.04 & 0.91 \\
\hline $8: 0$ & 1.49 & 1.45 & 1.49 & 1.44 & 0.056 & 0.20 & 0.20 & 0.76 \\
\hline 10:0 & 3.53 & 3.42 & 3.50 & 3.37 & 0.197 & 0.22 & 0.20 & 0.82 \\
\hline $14: 0$ & 11.7 & 11.3 & 11.7 & 11.5 & 0.24 & 0.34 & 0.97 & 0.42 \\
\hline $14: 0$ iso & 0.10 & 0.09 & 0.11 & 0.12 & 0.009 & 0.80 & 0.26 & 0.37 \\
\hline $14: 1$ & 1.10 & 1.07 & 1.12 & 1.14 & 0.055 & 0.83 & 0.24 & 0.42 \\
\hline $15: 0$ & 0.99 & 0.95 & 1.08 & 1.18 & 0.037 & 0.08 & $<0.001$ & 0.11 \\
\hline 15:0 anteiso & 0.19 & 0.20 & 0.20 & 0.21 & 0.007 & 0.19 & 0.08 & 0.85 \\
\hline $16: 0$ & 28.2 & 28.5 & 28.2 & 28.0 & 0.50 & 0.99 & 0.59 & 0.59 \\
\hline $17: 1$ & 0.15 & 0.18 & 0.18 & 0.19 & 0.014 & 0.01 & 0.01 & 0.35 \\
\hline $18: 0$ & 11.1 & 11.4 & 11.4 & 11.4 & 0.45 & 0.39 & 0.60 & 0.50 \\
\hline trans-4 18:1 & 0.02 & 0.02 & 0.02 & 0.02 & 0.002 & 0.23 & 0.78 & 0.16 \\
\hline trans-5 18:1 & 0.02 & 0.01 & 0.01 & 0.01 & 0.003 & 0.15 & 0.39 & 0.11 \\
\hline trans- $6,8 \quad 18: 1$ & 0.27 & 0.27 & 0.26 & 0.26 & 0.004 & 0.06 & 0.02 & 0.95 \\
\hline trans-9 18:1 & 0.20 & 0.20 & 0.20 & 0.20 & 0.010 & 0.22 & 0.25 & 0.52 \\
\hline trans-10 18:1 & 0.41 & 0.39 & 0.38 & 0.38 & 0.022 & 0.06 & 0.04 & 0.56 \\
\hline trans-11 18:1 & 0.96 & 0.98 & 0.95 & 0.95 & 0.024 & 0.98 & 0.64 & 0.64 \\
\hline trans-12 18:1 & 0.34 & 0.32 & 0.33 & 0.33 & 0.007 & 0.08 & 0.19 & 0.30 \\
\hline cis-9 18:1 & 17.7 & 18.1 & 17.4 & 17.9 & 1.11 & 0.71 & 0.99 & 0.98 \\
\hline cis-11 18:1 & 0.83 & 0.82 & 0.87 & 0.91 & 0.031 & 0.31 & 0.03 & 0.32 \\
\hline cis-12 18:1 & 0.38 & 0.37 & 0.38 & 0.40 & 0.013 & 0.76 & 0.22 & 0.35 \\
\hline $18: 2 \mathrm{n}-6$ & 2.99 & 2.91 & 3.06 & 3.16 & 0.048 & 0.42 & 0.02 & 0.13 \\
\hline $18: 3$ & 0.40 & 0.40 & 0.41 & 0.42 & 0.008 & 0.44 & 0.07 & 0.27 \\
\hline $6: 0$ & 40.0 & 39.4 & 37.0 & 38.5 & 1.68 & 0.23 & 0.20 & 0.41 \\
\hline $8: 0$ & 23.1 & 22.9 & 21.5 & 22.3 & 0.74 & 0.31 & 0.24 & 0.51 \\
\hline 10:0 & 54.3 & 53.8 & 50.4 & 52.1 & 1.53 & 0.29 & 0.22 & 0.53 \\
\hline $11: 0$ & 1.27 & 1.13 & 1.14 & 1.36 & 0.078 & 0.57 & 0.49 & 0.06 \\
\hline $12: 0$ & 59.7 & 59.0 & 55.5 & 57.5 & 1.63 & 0.27 & 0.23 & 0.46 \\
\hline $13: 0$ & 1.96 & 1.82 & 1.83 & 2.13 & 0.138 & 0.74 & 0.28 & 0.04 \\
\hline $14: 0$ & 179.7 & 176.3 & 168.1 & 178.7 & 7.95 & 0.33 & 0.59 & 0.15 \\
\hline $14: 0$ iso & 1.61 & 1.48 & 1.56 & 1.83 & 0.185 & 0.97 & 0.36 & 0.25 \\
\hline $14: 1$ & 17.2 & 16.7 & 16.2 & 17.7 & 1.78 & 0.56 & 0.58 & 0.04 \\
\hline $15: 0$ & 15.0 & 14.7 & 15.5 & 18.2 & 0.86 & 0.08 & $<0.001$ & 0.009 \\
\hline 15:0 anteiso & 2.98 & 3.10 & 2.91 & 3.31 & 0.251 & 0.46 & 0.22 & 0.31 \\
\hline $16: 0$ & 436.2 & 441.9 & 407.0 & 434.7 & 20.27 & 0.49 & 0.40 & 0.30 \\
\hline 16:0 iso & 3.57 & 3.41 & 3.50 & 4.11 & 0.288 & 0.74 & 0.16 & 0.16 \\
\hline $16: 1$ & 17.0 & 16.4 & 15.8 & 17.3 & 2.57 & 0.62 & 0.95 & 0.25 \\
\hline $17: 0$ & 7.35 & 7.54 & 7.17 & 7.91 & 0.531 & 0.58 & 0.33 & 0.36 \\
\hline 17:0 iso & 0.75 & 0.77 & 0.76 & 0.82 & 0.042 & 0.45 & 0.24 & 0.58 \\
\hline 17:0 anteiso & 3.96 & 4.05 & 3.96 & 4.24 & 0.339 & 0.47 & 0.27 & 0.53 \\
\hline $17: 1$ & 2.34 & 2.83 & 2.57 & 2.89 & 0.402 & 0.04 & 0.07 & 0.62 \\
\hline 18:0 & 17.0 & 182.3 & 164.8 & 175.4 & 8.38 & 0.91 & 0.80 & 0.94 \\
\hline trans-4 18:1 & 0.35 & 0.24 & 0.27 & 0.32 & 0.034 & 0.14 & 0.76 & 0.06 \\
\hline trans-5 18:1 & 0.24 & 0.19 & 0.12 & 0.20 & 0.048 & 0.13 & 0.31 & 0.10 \\
\hline trans-6,8 18:1 & 4.25 & 4.18 & 3.79 & 4.01 & 0.268 & 0.13 & 0.09 & 0.33 \\
\hline
\end{tabular}


Table 9 (Continued). Effect of 2-hydroxy-4-methylthio-butanoic acid (HMTBa) on milk fatty acid concentration in total milk fat or yield

\begin{tabular}{|c|c|c|c|c|c|c|c|c|}
\hline \multirow[b]{2}{*}{ Item } & \multicolumn{4}{|c|}{$\operatorname{Diet}^{1,2}$} & \multirow[b]{2}{*}{ SEM } & \multicolumn{3}{|c|}{ Contrast $^{3}$} \\
\hline & Control & Low & Medium & High & & $\mathrm{C}$ vs. $\mathrm{Tr}$ & $\mathrm{L}$ & $\mathrm{Q}$ \\
\hline trans-10 18:1 & 6.35 & 6.08 & 5.51 & 5.84 & 0.708 & 0.03 & 0.03 & 0.13 \\
\hline trans-11 18:1 & 14.8 & 15.2 & 13.8 & 14.7 & 0.85 & 0.77 & 0.52 & 0.75 \\
\hline trans-12 18:1 & 5.28 & 5.04 & 4.71 & 5.06 & 0.278 & 0.08 & 0.18 & 0.09 \\
\hline cis-9 18:1 & 273.1 & 285.0 & 249.8 & 275.4 & 36.48 & 0.83 & 0.59 & 0.56 \\
\hline $18: 2 \mathrm{n}-6$ & 46.1 & 45.5 & 43.6 & 48.6 & 3.69 & 0.88 & 0.47 & 0.10 \\
\hline $18: 3$ & 6.21 & 6.11 & 5.83 & 6.52 & 0.500 & 0.82 & 0.48 & 0.07 \\
\hline $20: 0$ & 2.09 & 2.20 & 2.02 & 2.15 & 0.091 & 0.75 & 0.97 & 0.91 \\
\hline cis-9,trans-11 CLA & 6.85 & 6.82 & 6.25 & 6.75 & 0.965 & 0.31 & 0.34 & 0.20 \\
\hline Other & 42.6 & 42.9 & 40.6 & 46.1 & 3.83 & 0.67 & 0.13 & 0.04 \\
\hline$\Sigma<16$ (de novo) & 468.1 & 459.9 & 437.0 & 462.0 & 19.43 & 0.31 & 0.47 & 0.20 \\
\hline$\Sigma>16$ (preformed) & 574.8 & 595.7 & 535.7 & 584.0 & 52.20 & 0.91 & 0.76 & 0.57 \\
\hline
\end{tabular}

${ }^{1}$ Control $=0 \%$ (diet DM basis) HMTBa (as Alimet, Novus International Inc., St. Charles, MO); low $=0.05 \%$ HMTBa; medium $=0.10 \%$ HMTBa; high $=0.15 \%$ HMTBa.

${ }^{3}$ Least squares means; $\mathrm{n}=32$ ( $\mathrm{n}$ represents number of observations used in the statistical analysis).

${ }^{3} \mathrm{C}$ vs. $\mathrm{Tr}=$ control vs. HMTBa treatments; $\mathrm{L}=$ linear effect of HMTBa; $\mathrm{Q}=$ quadratic effect of HMTBa.

experiment resulted in low levels of trans-10, 18:1 and no evidence of diet induced milk fat depression, limiting the ability to observe a larger treatment effect.

Plasma Met concentration was not affected by treatment $(21.2,21.1,20.2$, and $20.6 \mu \mathrm{mol} / \mathrm{L}$ for control, low, medium, and high HMTBa, respectively; SEM = $\left.1.31 ; \mathrm{n}=95 ; P_{\mathrm{L}}=0.64, P_{\mathrm{Q}}=0.81\right)$ in the current experiment. Koenig et al. $(1999,2002)$ and Zanton et al. (2014) reported increased serum Met concentrations with pulse-dosed intraruminal administration of HMTBa. Similar to the results from the current experiment, however, plasma Met was not affected by feeding HMTBa in the study by Rulquin et al. (2006).

\section{CONCLUSIONS}

Feed intake, milk production, and milk composition were not affected by HMTBa in this crossover experiment. The observed decrease in apparent, total-tract digestibility of $\mathrm{CP}$ (and the associated increase in fecal $\mathrm{N}$ losses) and starch are difficult to explain. There were no well-defined effects of HMTBa on ruminal fermentation and bacterial genus and species composition, but the concentration of microbial $\mathrm{N}$ in reticular contents tended to numerically increase and the estimated microbial $\mathrm{N}$ production in the rumen linearly increased with increasing HMTBa application rate. These effects were in line with the observed increase in 15:0 (and to a lesser extent 17:0) FA concentration and yield in milk fat. Overall, the rumen and milk FA data from this experiment seem to suggest a positive effect of HMTBa on microbial protein sysnthesis in the rumen.

\section{ACKNOWLEDGMENTS}

This study was partially supported by funds from Novus International Inc. (St. Charles, MO). The authors thank the staff of the Department of Animal Science Dairy Center for their conscientious care of the experimental cows. The authors also thank S. Dowd (Molecular Research DNA) for performing the microbial molecular analyses and W. Price (Statistical Programs, College of Agricultural and Life Sciences, University of Idaho) for assistance with statistical analysis of the data.

\section{REFERENCES}

AOAC International. 2000. Official Methods of Analysis. 17th ed. AOAC Int., Arlington, VA.

AOAC International. 2002. Official Methods of Analysis. 17th ed. 1st rev. ed. AOAC Int., Arlington, VA.

Baldin, M., J. Y. Ying, G. I. Zanton, and K. J. Harvatine. 2014. Effect of 2-hydroxy-4-(methylthio)butanoate (HMTBa) on risk of dietinduced milk fat depression. J. Dairy Sci. 97(E-Suppl. 1):358. (Abstr.)

Binnerts, W. T., A. T. Van`t Klooster, and A. M. Frens. 1968. Soluble chromium indicator measured by atomic absorption in digestion experiments. Vet. Rec. 82:470.

Broderick, G. A., T. Kowalczyk, and L. D. Satter. 1970. Milk production response to supplementation with encapsulated methionine per os or casein per abomasum. J. Dairy Sci. 53:1714-1721.

Broderick, G. A., L. D. Satter, and A. E. Harper. 1974. Use of plasma amino acid concentration to identify limiting amino acids for milk production. J. Dairy Sci. 57:1015-1023.

Caporaso, J. G., C. L. Lauber, W. A. Walters, D. Berg-Lyons, C. A. Lozupone, P. J. Turnbaugh, N. Fierer, and R. Knight. 2011. Global patterns of 16S rRNA diversity at a depth of millions of sequences per sample. Proc. Natl. Acad. Sci. USA 108:4516-4522.

Chen, X. B., Y. K. Chen, M. F. Franklin, E. R. Ørskov, and W. J. Shand. 1992. The effect of feed intake and body weight on purine 
derivative excretion and microbial protein supply in sheep. J. Anim. Sci. 70:1534-1542.

Chen, Z. H., G. A. Broderick, N. D. Luchini, B. K. Sloan, and E. Devillard. 2011. Effect of feeding different sources of rumen-protected methionine on milk production and N-utilization in lactating dairy cows. J. Dairy Sci. 94:1978-1988.

Combs, D. K., and L. D. Satter. 1992. Determination of markers in digesta and feces by direct current plasma emission spectroscopy. J. Dairy Sci. 75:2176-2183.

Cotta, M. A., and J. B. Russell. 1982. Effect of peptides and amino acids on efficiency of rumen bacterial protein synthesis in continuous culture. J. Dairy Sci. 65:226-234

DeSantis, T. Z., P. Hugenholtz, N. Larsen, M. Rojas, E. L. Brodie, K. Keller, T. Huber, D. Dalevi, P. Hu, and G. L. Andersen. 2006 Greengenes, a chimera-checked 16S rRNA gene database and workbench compatible with ARB. Appl. Environ. Microbiol. 72:5069-5072.

DeVries, T. J., M. A. G. von Keyserlingk, and K. A. Beauchemin. 2003. Short Communication: Diurnal feeding pattern of lactating dairy cows. J. Dairy Sci. 86:4079-4082.

Dewhurst, R. J., J. M. Moorby, B. Vlaeminck, T. Van Nespen, and V. Fievez. 2007. Apparent recovery of duodenal odd- and branchedchain fatty acids in milk. J. Dairy Sci. 90:1775-1780.

Dibner, J. J. 2003. Review of the metabolism of 2-hydroxy-4- (methylthio) butanoic acid. World's Poult. Sci. J. 59:99-110.

Dijkstra, J., S. M. van Zijderveld, J. A. Apajalahti, A. Bannink, W. J. J. Gerrits, J. R. Newbold, H. B. Perdok, and H. Berends. 2011. Relationships between methane production and milk fatty acid profiles in dairy cattle. Anim. Feed Sci. Technol. 166-167:590-595.

Fievez, V., E. Colman, J. M. Castro-Montoya, I. Stefanov, and B. Vlaeminck. 2012. Milk odd- and branched-chain fatty acids as biomarkers of rumen function-An update. Anim. Feed Sci. Technol. 172:51-65.

France, J., and R. C. Siddons. 1986. Determination of digesta flow by continuous marker infusion. J. Theor. Biol. 121:105-120.

French, E. A., S. J. Bertics, and L. E. Armentano. 2012. Rumen and milk odd- and branched-chain fatty acid proportions are minimally influenced by ruminal volatile fatty acid infusions. J. Dairy Sci. 95:2015-2026

Griel, L. C. Jr., R. A. Patton, R. D. McCarthy, and P. T. Chandler. 1968. Milk production response to feeding methionine hydroxyl analog to lactating dairy cows. J. Dairy Sci. 51:1866-1868.

Holter, J. B., C. W. Kim, and N. F. Colovos. 1972. Methionine hydroxy analog for lactating dairy cows. J. Dairy Sci. 55:460-465.

Hristov, A. N. 2007. Comparative characterization of reticular and duodenal digesta and possibilities to estimate microbial outflow from the rumen based on reticular sampling in dairy cows. J. Anim. Sci. 85:2606-2613.

Hristov, A. N., C. Lee, T. Cassidy, M. Long, K. Heyler, B. Corl, and R. Forster. 2011. Effects of lauric and myristic acids on ruminal fermentation, production, and milk fatty acid composition in lactating dairy cows. J. Dairy Sci. 94:382-395.

Hristov, A. N., C. Lee, R. A. Hristova, P. Huhtanen, and J. Firkins. 2012. A meta-analysis of the variability in continuous culture rumen fermentation and digestibility data. J. Dairy Sci. 95:52995307.

Hristov, A. N., T. A. McAllister, D. R. Ouellet, and G. A. Broderick. 2005b. Comparison of purines and nitrogen-15 as microbial flow markers in beef heifers fed barley- or corn-based diets. Can. J. Anim. Sci. 85:211-222.

Hristov, A. N., and J. K. Ropp. 2003. Effect of dietary carbohydrate composition and availability on utilization of ruminal ammonia nitrogen for milk protein synthesis in dairy cows. J. Dairy Sci. $86: 2416-2427$.

Hristov, A. N., J. K. Ropp, K. L. Grandeen, S. Abedi, R. P. Etter, A. Melgar, and A. E. Foley. 2005a. Effect of carbohydrate source on ammonia utilization in lactating dairy cows. J. Anim. Sci. $83: 408-421$.

Hristov, A. N., M. Vander Pol, M. Agle, S. Zaman, C. Schneider, P. Ndegwa, V. K. Vaddella, K. Johnson, K. J. Shingfield, and S. K.
Karnati. 2009. Effect of lauric acid and coconut oil on ruminal fermentation, digestion, ammonia losses from manure, and milk fatty acid composition in lactating cows. J. Dairy Sci. 92:5561-5582.

Huber, J. T., R. S. Emery, W. G. Bergen, J. S. Liesman, L. Kung, K. J. King, R. W. Gardner, and M. Checketts. 1984. Influences of methionine hydroxy analog on milk and milk fat production, blood serum lipids, and plasma amino acids. J. Dairy Sci. 67:2525-2531.

Huhtanen, P., K. Kaustell, and S. Jaakkola. 1994. The use of internal markers to predict total digestibility and duodenal flow of nutrients in cattle given six different diets. Anim. Feed Sci. Technol. 48:211-227.

Jendza, J. A., P. A. Geraert, D. Ragland, and O. Adeola. 2011. The site of intestinal disappearance of DL-methionine and methionine hydroxy analog differs in pigs. J. Anim. Sci. 89:1385-1391.

Johnson-VanWieringen, L. M., J. H. Harrison, D. Davidson, M. L. Swift, M. A. G. von Keyserlingk, M. Vazquez-Anon, D. Wright, and W. Chalupa. 2007. Effects of rumen undegradable protein sources and supplemental 2-hydroxy-4-(methylthio)-butanoic acid and lysine- $\mathrm{HCl}$ on lactation performance in dairy cows. J. Dairy Sci. 90:5176-5188.

Karnati, S. K. R., J. T. Sylvester, S. M. Noftsger, Z. Yu, N. R. StPierre, and J. L. Firkins. 2007. Assessment of ruminal bacterial populations and protozoal generation time in cows fed different methionine sources. J. Dairy Sci. 90:798-809.

Keeney, M., I. Katz, and M. J. Allison. 1962. On the probable origin of some milk fat acids in rumen microbial lipids. J. Am. Oil Chem. Soc. 39:198-201.

Knight, C. D., and A. J. Dibner. 1984. Comparative absorption of 2-hydroxy-4-(methylthio)-butanoic acid and L-methionine in the broiler chick. J. Nutr. 114:2179-2186.

Knudsen, K. E. B. 1997. Carbohydrate and lignin contents of plant materials used in animal feeding. Anim. Feed Sci. Technol. $67: 319-338$.

Koenig, K. M., L. M. Rode, C. D. Knight, and P. R. McCullough 1999. Ruminal escape, gastrointestinal absorption, and response of serum methionine to supplementation of liquid methionine hydroxy analog in dairy cows. J. Dairy Sci. 82:355-361.

Koenig, K. M., L. M. Rode, C. D. Knight, and M. Vazquez-Añon. 2002. Rumen degradation and availability of various amounts of liquid methionine hydroxy analog in lactating dairy cows. J. Dairy Sci. 85:930-938.

Lapierre, H., M. Vázquez-Añón, D. Parker, P. Dubreuil, G. Holtrop, and G. E. Lobley. 2011. Metabolism of 2-hydroxy-4-(methylthio) butanoate (HMTBA) in lactating dairy cows. J. Dairy Sci. 94:1526-1535.

Lee, C., A. N. Hristov, T. W. Cassidy, K. S. Heyler, H. Lapierre, G. A. Varga, M. J. de Veth, R. A. Patton, and C. Parys. 2012. Rumenprotected lysine, methionine, and histidine increase milk protein yield in dairy cows fed a metabolizable protein-deficient diet. J. Dairy Sci. 95:6042-6056.

Lobley, G. E., T. J. Wester, A. G. Calder, D. S. Parker, J. J. Dibner, and M. Vázquez-Añón. 2006. Absorption of 2-hydroxy-4-methylthiobutyrate and conversion to methionine in lambs. J. Dairy Sci. 89:1072-1080.

Lundquist, R. G., J. G. Linn, and D. E. Otterby. 1983. Influence of dietary energy and protein on yield and composition of milk from cows fed methionine hydroxyl analog. J. Dairy Sci. 66:475-491.

Martin, C., C. Mirande, D. P. Morgavi, E. Forano, E. Devillard, and P. Mosoni. 2013. Methionine analogues HMB and HMBi increase the abundance of cellulolytic bacterial representatives in the rumen of cattle with no direct effects on fibre degradation. Anim. Feed Sci. Technol. 182:16-24.

McCollum, M. Q., M. Vázquez-Añón, J. J. Dibner, and K. E. Webb. 2000. Absorption of 2-hydroxy-4-(methylthio)butanoic acid by isolated sheep ruminal and omasal epithelia. J. Anim. Sci. 78:10781083 .

Mohammed, R., S. M. McGinn, and K. A. Beauchemin. 2011. Prediction of enteric methane output from milk fatty acid concentrations and rumen fermentation parameters in dairy cows fed sunflower, flax, or canola seeds. J. Dairy Sci. 94:6057-6068. 
Noftsger, S., N. R. St-Pierre, and J. T. Sylvester. 2005. Determination of rumen degradability and ruminal effects of three sources of methionine in lactating cows. J. Dairy Sci. 88:223-237.

Noftsger, S. M., N. R. St-Pierre, S. K. R. Karnati, and J. L. Firkins. 2003. Effects of 2-hydroxy-4-(methylthio) butanoic acid (HMB) on microbial growth in continuous culture. J. Dairy Sci. 86:26292636.

NRC. 2001. Nutrient Requirements of Dairy Cattle. 7th rev. ed. Natl. Acad. Sci. Washington, DC.

Piepenbrink, M. S., A. L. Marr, M. R. Waldron, W. R. Butler, T. R. Overton, M. Vazquez-Añon, and M. D. Holt. 2004. Feeding 2-hydroxy-4-(methylthio)-butanoic acid to periparturient dairy cows improves milk production but not hepatic metabolism. J. Dairy Sci. 87:1071-1084.

Rico, D. E., and K. J. Harvatine. 2013. Induction of and recovery from milk fat depression occurs progressively in dairy cows switched between diets that differ in fiber and oil concentration. J. Dairy Sci. 96:6621-6630.

Rulquin, H., B. Graulet, L. Delaby, and J. C. Robert. 2006. Effect of different forms of methionine on lactational performance of dairy cows. J. Dairy Sci. 89:4387-4394.

Russell, J. B. 1993. Effect of amino acids on the heat production and growth efficiency of Streptococcus bovis: balance of anabolic and catabolic rates. Appl. Environ. Microbiol. 59:1747-1751.

Schneider, B. H., and W. P. Flatt. 1975. The evaluation of feeds through digestibility experiments. University of Georgia Press, Athens, GA.

Schwab, C. G., L. D. Satter, and A. B. Clay. 1976. Response of lactating dairy cows to abomasal infusion of amino acids. J. Dairy Sci. 59:1254-1270.

Sklan, D., and M. Tinsky. 1996. Production responses of high producing cows fed rumen bypass DL-2-hydroxy-4-(methylthio) butanoic acid coated with calcium soaps of fatty acids. Livest. Prod. Sci. 45:149-154.

St-Pierre, N. R., and J. T. Sylvester. 2005. Effects of 2-hydroxy4-(methylthio) butanoic acid (HMB) and its isopropyl ester on milk production and composition by Holstein cows. J. Dairy Sci. $88: 2487-2497$
Uchida, K., P. Mandebvu, C. S. Ballard, C. J. Sniffen, and M. P. Carter. 2003. Effect of feeding methionine supplements with different rumen escape values on performance of high producing dairy cows in early lactation. Anim. Feed Sci. Technol. 107:1-14.

Van Kessel, J. S., and J. B. Russell. 1996. The effect of amino nitrogen on the energetics of ruminal bacteria and its impact on energy spilling. J. Dairy Sci. 79:1237-1243.

Van Soest, P. J., J. B. Robertson, and B. A. Lewis. 1991. Methods for dietary fiber, neutral detergent fiber, and nonstarch polysaccharides in relation to animal nutrition. J. Dairy Sci. 74:3583-3597.

Vazquez-Añon, M., T. Cassidy, P. McCullough, and G. A. Varga. 2001. Effects of Alimet on nutrient digestibility, bacterial protein synthesis, and ruminal disappearance during continuous culture. J. Dairy Sci. 84:159-166.

Vazquez-Añon, M., R. Gonzalez-Esquerra, I. G. Yi, and C. D. Knight. 2006. A multiple regression model approach to contrast the performance of 2-hydroxy-4-methylthio butanoci acid and DL-methionine supplementation tested in broiler experiments and reported in the literature. Poult. Sci. 85:693-705.

Vedenov, D., and G. M. Pesti. 2010. An economic analysis of methionine source comparison response model. Poult. Sci. 89:2514-2520.

Vlaeminck, B., V. Fievez, A. R. J. Cabrita, A. J. M. Fonseca, and R. J. Dewhurst. 2006. Factors affecting odd- and branched-chain fatty acids in milk: A review. Anim. Feed Sci. Technol. 131:389-417.

Wang, C., H. Y. Liu, Y. M. Wang, Z. Q. Yang, J. X. Liu, Y. M. Wu, T. Yan, and H. W. Ye. 2010. Effects of dietary supplementation of methionine and lysine on milk production and nitrogen utilization in dairy cows. J. Dairy Sci. 93:3661-3670.

Zanton, G. I., S. E. Bettis, and M. Vazquez-Anon. 2014. Plasma Lmethionine and supplemental L-methionine precursor responses to rumen administration of a rumen protected DL-methionine source or different levels of 2-hydroxy-4-methylthio-butanoic acid. J Dairy Sci. 97(E-Suppl. 1):755. (Abstr.)

Zelenka, J., J. Heger, V. Machander, M. Wiltafsky, and M. Lešták. 2013. Bioavailability of liquid methionine hydroxy analogue-free acid relative to DL-methionine in broilers. Acta Univ. Agric. Silv. Mendelianae Brunensis 168:1513-1520. 